\title{
LAYANAN BIMBINGAN DAN KONSELING PRIBADI SOSIALDALAM MENUMBUHKAN SIKAP POSITIF SISWA
}

\author{
Ina Ambar Wati \\ e-mail: inaqolbu29@gmail.com \\ MahasiswaPascasarjana BimbinganKonseling Islam \\ UIN Sunan Kalijaga Yogyakarta
}

\begin{abstract}
There are still many students who violate the rules at school making them hampered to achieve success. Not only that, if this is left unchecked, it will make the character of students not good. The purpose of writing this journal is to find out the right way so that each student can obey the discipline at school. Where if this can be done surely the system and purpose of an institution will be easily achieved. Personal social guidance and counseling services are an alternative as an effort to make students obey the rules. Counseling services emphasize change in addressing discipline. By changing negative attitudes such as breaking the rules into a positive attitude that is obeying the order. Learners' positive attitudes toward discipline can be used as an alternative to changing the rules of curbing and burdensome dicipline into something very useful. And can make students carry out their responsibilities from their heart and willingness not because of coercion or fear of blasphemy, because obeying the rules will lead students to success.
\end{abstract}

Keyword: Counseling, Personal social, positive attitude 


\begin{abstract}
Abstrak
Masih banyaknya peserta didik yang melanggar tata tertib di sekolah menjadikan mereka terhambat untuk meraih kesuksesan. Tidak hanya itu jika hal ini dibiarkan akan menjadikan karakter peserta didik menjadi tidak baik. Tujuan penulisan ini ialah untuk mengetahui cara yang tepat agar setiap peserta didik bisa mematuhi tata tertib di sekolah. Dimana jika hal tersebut dapat terlaksana pastilah sistem dan tujuan suatu lembaga akan mudah tercapai. Layanan bimbingan dan konseling pribadi-sosial menjadi alternatif sebagai upaya untuk menjadikan peserta didik mematuhi tata tertib. Layanan konseling menekankan perubahan dalam menyikapi tata tertib. Dengan cara mengubah sikap negatif seperti melanggar tata tertib menjadi sikap positif yakni mematuhi tata tertib. Sikap positif peserta didik terhadap tata tertib dapat dijadikan sebagai alternatif untuk mengubah aturan tata tertib yang mengekang dan membebani menjadi sesuatu yang sangat bermanfaat serta dapat menjadikan peserta didik melaksanakan tanggung jawabnya dari hati dan kemaunnya sendiri bukan karena paksaan ataupun takut hukaman, karena mematuhi tata tertib akan mengantarkan peserta didik pada kesuksesan.
\end{abstract}

Kata Kunci: Konseling, PribadiSosial, Sikap Positif 


\section{A. Pendahuluan}

Konseling merupakan sumbangsih ilmu yang sangat penting. Dalam Pendidikan tidak bisa terlepas dari konseling. Keduanya saling membutuhkan. Long life education yang berarti pendidikan seumur hidup. setiap lembaga pendidikan pasti akan melakukan berbagai inovasi agar sistem pendidikan yang dikelolanya berjalan dengan efektif dan menghasilkan alumnus yang berprestasi dan membanggakan.Lembaga pendidikan yang berjalan lancar pastinya memiliki tata tertib atau aturan yang berjalan dengan ketat dan displin. Tata tertib di sekolah menajadikan suatu lembaga berjalan pada arahnya untuk mencapai tujuan.

Namun, pada realitanya banyak terjadi kasus pelanggaran tata tertib disekolah. Tata tertib sendiri menjadi beban bagi peserta didik. Padahal di setiap lembaga pendidikan di dunia ini pasti memiliki tata tertib yang harus dilaksanakan. Semua hal perlu aturan agar dapat terkontrol dan terorganisir di jalan yang semestinya. Begitu juga dengan lembaga pendidikan, tata tertib di ciptakan agar semua pihak sekolah khususnya peserta didik mendapatkan proses belajar mengajar yang efektif dan lebih baik. bayangkan saja jika di sekolah tidak ada tertib pasti akan mengalami kekacauan seperti jalan lalu lintas yang tidak punya aturan. Akan terjadi kemacetan, kecelakaan dan marabahaya yang lainnya.

Hal ini senada dengan deskripsi hasil penelitian Putri yang dikutip oleh Eka Novia Anggraini dan Tjipto Subadi dalam jurnalnya yang berjudul Pengelolaan Tata Tertib Sekolah Menengah Pertama, bahwa untuk mencapai tujuan pendidikan yang telah ditentukan maka aktifitas siswa di sekolah perlu diatur dalam suatu aturan yang disebut tata tertib. Berarti dengan adanya tata tertib sekolah diharapkan dapat dijadikan ramburambu dalam berperilaku bagi semua siswa. Perencanaan tata tertib sekolah penting karena dengan adanya tata tertib sekolah maka tujuan sekolah dapat tercapai. ${ }^{1}$

Sikap positif manusia sudah dijelaskan dalam hadis yakni "Sungguh ajaib kondisi seorang muslim, seluruh kondisinya seorang mukmin, seluruh kondisinya pasti menjadi baik. Dan itu hanya dimiliki oleh seorang mukmin saja.Apabilaiamemperolehkenikmatan akan bersyukur, maka kesenangan itu akan menjadi kebaikan buat dirinya. Apabila ia tertimpa musibah, ia akan bersabar, dan musibah itu pun akan

1 Eka Novia Anggraini, Tjipto Subadi, "Pengelolaan Tata Tertib Sekolah Menengah Pertama", Varia Pendidikan,(Vol. 27, No. 2, Desember 2015), 146. 
menjadi kebaikan buat dirinya”. (HR, Muslim).

Layanan bimbingan dan konseling pribadi sosial adalah salah satu layanan yang disediakan dalam bimbingan konseling. Layanan ini digunakan untuk menjadikan siswa mengetahui akan apa yang harus dilakukan dalam mengeksplor tentang dirinya sendiri dan juga ranah sosialnya. Peserta didik yang melanggar tata tertib mereka mempunyai permasalahan. Yakni mereka belum menyadari akan tanggung jawabnya sebagai peserta didik dan manfaat dari tata tertib itu sendiri. Hal ini menjadikan konseling pribadi-sosial sangat dibutuhkan agar para peserta didik bisa merubah sikap negatifnya menjadi sikap positif dalam menjalankan tata tertib.

Dengan bersikap positif terhadap stimulus yang ada seperti halnya mematuhi tata tertib yang ada akan menjadikan aturan tersebut menjadi mudah dilaksanakan dan bukanlah sebuah aturan yang menyiksa. Hal inilah yang menjadi tugas seluruhelemen yangberkecimpung di dunia pendidikan. Mulai dari peserta didik, guru, orang tua, dan lingkungan masyarakat disekitar sekolah. warga dalam suatu lembaga pendidikan khususnya guru bimbingan dan konseling agar bisa menciptakan suatu perubahan besar yakni menjadikan siswanya bermental positif yang pada akhir akan melahirkan para pelajar yang disiplin akan tata tertib dan menjadikanya jalan untuk merah kesuksesan, setidaknya mereka sudah sukses melawan kemalasan yang ada dalam dirinya.

\section{B. Sikap Positif}

Menurut Azwar dan Purwanto dalam jurnal Umar Sulaiman. Azwar menjelaskan bahwa sikap sebagai suatu kecenderunganpotensi untuk bereaksi apabila individu dihadapkan pada suatu stimulus yang menghendaki adanya respons. Sedangkan Purwanto mengatakan bahwa sikap adalah suatu cara berpikir terhadap suatu perangsang atau suatu kecenderungan untuk bereaksi dengan cara tertentu terhadap suatu perangsang atau suatu kecenderungan untuk bereaksi dengan cara tertentu terhadap suatu perangsang atau situasi yang dihadapi. ${ }^{2}$ Berdasarkan penjelasan Azwar dan Purwanto dapat disimpulkan bahwa sikap adalah cara berfikir yang cenderung untuk bereaksi atau merespon karena adanya stimulus atau perangsang dengan cara tertentu.

2 Umar Sulaiman, "Analisis Pengetahuan, Sikap, Dan Perilaku Beragama SiswaKasus pada Siswa SLTP Negeri I dan MTs Negeri Bulukumba",Jurnal Auladuna,(Vol. 1 No. 2 Desember 2014), 204. 
Menurut Anderson dalam Budiyono yang dikutip oleh Ek Ajeng Rahmi Pinahayu dalam jurnalnya menyatakan bahwa sikap attitude merupakan kecenderungan untuk merespon secara positif favorable atau secara negatif unfavorable terhadap suatu objek. Fishbeindan Ajzen dalam Allan, et al menyebutkan bahwa sikap mempengaruhi tindakan seorang individu yang mempunyai beberapa tingkat konsistensi dan dapat dievaluasi sebagai negatif atau positif. ${ }^{3}$

Menurut penjelasan dari Andersin dan Fishbeinet al menjelaskan bahwa kecenderungan seseorang untuk merepson suatu objek yang menghasilkan respon secara positif maupun negatif.

\section{a. Struktur Sikap}

Menurut Azwar yang dikutip oleh Darmiyati Zuchdi dalam jurnalnya menjelaskan, dilihat dari structurnya, sikap terdiri atas tiga komponen yaitu komponen kognitif, komponen afektif, dankomponen konatif. Komponen kognitif berupa keyakinan seseorang (behavior belief dan groupbelief), komponen afektif menyangkut aspek emosional, dan komponenkonatif

3 Ek Ajeng Rahmi Pinahayu, "Menumbuhkan Sikap Positif Dan Kreativitas Peserta Didik Melalui Media Pembelajaran Mahjong Trigonometri”,Jurnal Ilmiah Pendidikan Matematika, (Volume 2 Nomor 1 $\operatorname{hlm} 21$. merupakan aspek kecenderungan bertindak sesuai dengan sikapnya. Komponen afektif atau aspek emosional biasanya berakar paling dalam sebagai komponen sikap, yang paling bertahan terhadap pengaruh yang mungkin mengubah sikap. ${ }^{4}$

\section{b. Komponen Kognitif}

Komponen Kognitif berisi persepsi, kepercayaan, dan stereotipe yang dimiliki individu mengenai sesuatu. Persepsi dan kepercayaan seseorang mengenai objek sikap berwujud pandangan (opini) dan seringkali merupakan stereotipe atau sesuatu yang telah terpolakan dalam pikirannya. Komponen kognitif dari sikap ini tidak selalu akurat. Kadangkadang kepercayaan justru timbul tanpa adanya informasi yangtepat mengenai suatu objek. Kebutuhan emosional bahkan sering merupakan determinan utama bagi terbentuknya kepercayaan.

\section{c. Komponen Afektif}

Komponen afektif melibatkan perasaan atau emosi. Reaksi emosional kita terhadap suatu objek akan membentuk sikap positif atau negatif terhadap objek tersebut. Reaksi emosional ini banyak ditentukan oleh kepercayaan terhadap suatu objek,

4 Darmiyati Zuchdi, "Pembentukan Sikap",Cakrawala pendidikan, (Nomor 3, Tahun XIV, November 1995),52. 
yakni kepercayaan suatu objekbaik atau tidak baik, bermanfaat atau tidak bermanfaat.

\section{d. Komponen Konatif}

Menurut Azwar Komponen konatif atau kecenderungan bertindak (berperilaku) dalam diri seseorang berkaitan dengan objek sikap. Perilaku seseorangdalam situasi tertentu dan dalam situasi menghadapi stimulus tertentu,banyak ditentukan oleh kepercayaan dan perasaannya terhadap stimulus tersebut. Kecenderungan berperilaku secara konsisten, selaras dengan kepercayaan dan perasaan ini membentuk sikap individual.

Sebagaihalnya karakteristik afektif yang lain, sikap memiliki target, arah, dan intensitas. Target ialah objek,. kegiatan, atau gagasan yang menjadi sasaran suatu sikap. Yang dimaksud dengan arah sikapialah orientasi sikap yang dapat positif atau negatif. Sedangkan intensitas adalah derajad atau kekuatan sikap. Sikap terhadap suatu objek dapat sangat kuat, misalnya sangat senang pada karya karya sastra atau sangatbenci pada perjudian.Arah dan intensitas sikap itu dapat digambarkan sebagai suatu kontinum. Titik tengah kontinum tersebut membedakan arah positif dan negatif, sedang jarak dari titik tengah menunjukkan intensitas sikap.

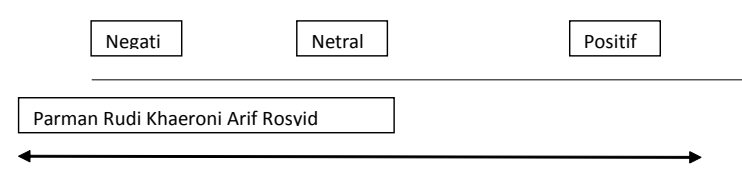

Perhatikan gambar berikut.

Gambar diatas Ilustrasi Kontinum sikap terhadap matematika(Adaptasi dari Anderson, 1981:4)Gambar di atas menunjukkan bahwa kelima anak yaitu Parman,Rudi, Khaeroni, Arif, dan Rosyid memiliki perbedaan sikap terhadapmatematika. Parman dan Rudi sarna-sarna memiliki sikap negatif terhadap matematika, tetapiintensitasnyaberbeda.Sedangkan Parman danRosyid memiliki intensitas sikap yang sam'a, tetapi Parman bersikap negatif sebaliknya Rosyid bersikap, positif. Demikian juga Rudi dan Arif.Yangterakhir Khaeroni, tidak jelas arah maupun intensitas sikapnyaterhadap matematika. ${ }^{5}$

e. Pembentukan Sikap

Menurut Azwar yang dikutip oleh Darmiyati Zuchdi dalam jurnalnya yang berjudul Pe,bentukkan Sikap menjelaskan Sikapsosialterbentukoleh ada.nya interaksisosial.Dalaminteraksi sosial itu, individu membentuk pola sikap tertentu terhadap objekpsikologis yang dihadapinya. Berbagai faktor yang mempengaruhi pembentukan sikap itu antara ialah pengalaman

5 Darmiyati Zuchdi, "Pembentukan Sikap.., 53-54. 
pribadi, kebudayaan,orang lain yang dianggap penting (signiffikan outher), media massa,lembaga pendidikan atau lembaga agama, dan faktor emosi dalam diri individu. Menyadari akan beberapa faktor tersebut, dalam mengajarkan sikap, masing-masing faktor secara sendiri- endiri atau bersama-sama harus dimanipulasi demi terbentuknya sikap positif yang kita kehendaki. ${ }^{6}$

f. Tata Tertib

Menurut Arikunto, peraturan tata tertib sekolah merupakan sebuah ketentuan maupun segala jenis pedoman yang harus di taati oleh semua warga sekolah. Aqib menjelaskan beberapa permasalahan ketidakdisiplinan dikelas atau disekolah diantaranya : makan di kelas;membuat suara gaduh; berbicara saat bukan gilirannya; lamban;mengganggu siswa; agresif; tidak rapi; melakukan ejekan; lupa; tidak memperhatikan; membaca materi lain; dan melakukan hal lain. ${ }^{7}$

Menurut Achmad Munib dalam jurnal Dwi Endro Lestari menyebutkan bahwa tata tertib sekolah adalah salah satu alat pendidikan preventif (pencegahan) yang bertujuan untuk

6 Ibid., 57.

7 Aprilia Nur Kurniawati, dkk, "Pengaruh Motivasi Terhadap Kedisiplinan Siswa Dalam Mematuhi Tata Tertib Sekolah Di Sekolah Menengah Atas (Sma) Al Islam 1 Surakarta”, Educitizen,(Vol. 2 No. 2. November, 2017), 39. menjaga agar hal-hal yang dapat menghambat atau mengganggu kelancaran proses pembelajaran dapat dihindarkan. $^{8}$

Menurut Hadianti dalam jurnal Eka Noviani Anggriani dan Tjipto Subadi, menjelaskan Tata tertib sekolah bukan hanya sekedar kelengkapan dari sekolah, tetapi merupakan kebutuhan yang harus mendapatkan perhatiandari semua pihak yang terkait, terutama daripelajar atau siswa itu sendiri. ${ }^{9}$

Tata tertib sebagai penentu akan keberhasilan proses pembelajaran di lembaga pendidikan. Hal ini sangat penting untuk di lakukan karena jika tata tertib tidak sepenuhnya di laksanakan oleh salah satu dari peserta didik di suatu lembaga pendidikan akan menghambat suatu keberhasilan peserta didik itu sendiri. Alangkah bagusnya jika semua peserta didik menjalankan hak serta kewajibannya sebagai seorang pelajar. Prestasi gemilang akan di raih, sikap disiplin dan mandiri setiap individu akan tumbuh serta proses belajar mengajar akan berjalan dengan efektif.

8 Dwi Endro Lestari, "Upaya Menangani Siswa Yang Sering Melanggar Tata Tertib Sekolah Melalui Layanan Konseling Kelompok",Jurnal Ilmiah Pendidikan Bimbingan Dan Konseling, 24-25.

9 Eka Noviani Anggriani dan Tjipto Subadi, "Pengelolaan Tata..., 144. 
g. Pelanggaran Tata Tertib

Pelanggaran tata tertib termasuk dalam contoh sikap negatif. Dimana seseorang belum memiliki sikap disiplin yang baik.Menurut Crow and Crow dalam Siti Meichati yang di kutip oleh Dwi Endro Lestari dalam jurnalnya mengemukakan bahwa: "Bentuk pelangggarantata tertib yang sering dilakukan siswa antara lain berupa terlambat datang ke sekolah, berkirim surat,membantah perintah, melalaikan tugas, membolos, berisik dalam kelas, ribut, ceroboh dalamtindakan, merusakbenda-benda, nakal (berkelahi), marah, bersikap asusila”. Sedangnkan menurut Gagne yang dikuti oleh Dwi Endro Lestari juga menyebutkan pelanggaran tata tertib adalah: "Sikap tidak perhatian, misalnya sering meninggalkankelas, bercakap-cakap selama pelajaran berlangsung, tidak menjawab pertanyaan guru, tidak mengerjakan tugas, lambat mengerjakan tugas" ${ }^{10}$

Tata tertib sebagai suatu sistem yang digunakan agar pelaksanaan pendidikan berjalan dengan lancar. Sikap peserta didik terhadap tata tertib adalah kecenderungan untuk mentaati atau melanngar tata tertib tersebut. Peserta didik yang memiliki sikap positif terhadap tata tertib memiliki

10 Dwi Endro Lestari, "Upaya Menangani Siswa...,25. ciri-ciri diantaranya menjalankan tata tertib dengan sungguh-sungguh, tidak pernah dihukum karena melanggar peraturan, meskipun melanggar dengan alasan yang pasti dan tidak di buat-buat. Dengan demikian, untuk menumbuhkan sikap positif terhadap tata tertib, guru bimbingan konseling hendaknya dapat memberikan konseling secara tuntas dan efektif agar siswa bisa merubah sikap mereka dan menjalankan tata tertib dengan baik.

\section{Layanan Bimbingan dan Konseling Pribadi Sosial}

Menurut Kartadinata dalam jurnal Nadya Yulianty $S$ menjelaskan Bimbingan, sebagai upaya pendidikan diartikansebagaiprosesbantuankepada individu untuk mencapai tingkat perkembangan diri secara optimum didalam menavigasi hidupnya secara mandiri. Perkembangan optimum dalam menavigasi hidup secara mandiri adalah suatu konsep normatif, suatu kondisi adekuat dimana individu mampu melakukan pilihan dan pengambilan keputusan yang tepat untukmempertahankan keberfungsian dirinya didalamsistemataulingkungan. Kondisi perkembangan optimum adalah kondisi dinamisyang ditandai dengan kesiapan dan kemampuan individu untuk memperbaikidiri selfimiprovemdent agar dia menjadi pribadi 
yang berfungsi penuh fullyfunctioning person di dalam lingkungannya. ${ }^{11}$

Menurut Syamsu Yusuf dan A. Juntika Nurihsan dalam jurnal Nadya Yulianty S menjelaskan bahwa visi bimbingan bersifat edukatif, pengembangan dan outreach. Edukatif, artinya kepedulian bimbingan terletak pada upaya pencegahan dan pengembangan danbukan pada upaya korektif dan terapeutik. Pengembangan, artinya titik sentral tujuan bimbingan terletak pada upaya memberdayakan seluruh potensi manusia melalui perekayasaan lingkungan perkembangan. Sedangkan outreach, disebabkan karena target bimbingan tidak terbatas pada individu yangbermasalah tetapi semua individu berkenaan dengan aspek kepribadiannyadalam semua konteks kehidupannya, meliputi berbagai ragam dimensi masalah,target intervensi, setting, metode, dan waktu layanan. ${ }^{12}$

Menurut Abu Ahmadi dalam jurnal Emmi Kholilah Harahap menjelaskan Bimbinganpribadi-sosial adalah, seperangkat usaha bantuan kepada pesertadidik agar dapat mengahadapi

11 Nadya Yulianty S, "Efektivitas Bimbingan Pribadi-Sosial Untuk Mengembangkan Kompetensi Intrapersonal Peserta Didik",Jurnal Bimbingan dan Konseling. Islam, (Vol. 05. No. 01. 2015), 33.

12 Ibid., 34. sendiri masalah-masalah pribadi dan sosial yang dialaminya, mengadakan penyesuaian pribadi dan sosial, memilih kelompok sosial, memilih jenis-jenis kegiatansosial dan kegiatan rekreatif yang bernilai guna, serta berdayaupaya sendiri dalam memecahkan masalahmasalah pribadi,rekreasi dan sosial yang dialaminya. ${ }^{13}$

Layanan bimbingan dan konseling pribadi-sosial adalah layanan konseling yang diberikan khusus untuk menangani masalah pribadi dan sosial yang dialami seorang klien. Layanan konseling diberikan yang di tujukan agar klien mampu mengubah sikap dan perilaku yang tidak baik menjadi lebih baik dan dengan keinginannya sendiri.

1. Tujuan Bimbingan Pribadi-Sosial

Syamsu Yusuf dalam jurnal Yahya AD dan Winarsih secara rincimenyebutkan tujuan yang ingin dicapai dari layanan bimbingan pribadisosial adalah sebagai berikut: ${ }^{14}$

a. Memiliki komitmen yang kuat dalammengamalkan nilai-

13 Emmi Kholilah Harahap, "Layanan Bimbingan Dan Konseling Pribadi Sosial Dalam Meningkatkan Keterampilan Hubungan Sosial Siswa", TAJDID, (Vol. XIV, No. 2, JuliDesember 2015), 286.

14 Yahya AD dan Winarsih, "Layanan Bimbingan Pribadi-Sosial Dalam Meningkatkan Komunikasi Interpersonal Peserta Didik Kelas Xi Sma Negeri 2 Padang Cermin Kabupaten Pesawaran",Jurnal Bimbingan dan Konseling,(ISSN 2089-9955 03, 1, 2016), 3-4. 
nilai keimanan dan ketaqwaan kepada tuhan yang maha esa, baik dalam kehidupan pribadi, keluarga, pergaulan dengan teman sebaya, sekolah, tempat kerja maupun masyarakat pada umumnya;

b. Memiliki sifat toleransi terhadap umat beragama lain dengan saling menghormati dan memelihara hak dan kewajibannya masing-masing;

c. Memiliki pemahaman tentang irama kehidupan yang bersifat fluktuatif antara yang menyenangkan dan tidak menyenangkan serta mampu meresponnya secara positif sesuai dengan ajaran agama yang dianutnya;

d. Memiliki pemahaman dan penerimaandiri secara objektif dan konstruktif, baik yang terkait dengan keunggulan maupun kelemahan baik fisik maupunpsikis;

e. Memiliki sifat positif atau respek terhadap diri sendiri dan orang lain;

f. Memiliki kemampuan untuk melakukan pilihan secara sehat;

g. bersikap respek terhadap orang lain, menghormati atau menghargai orang lain, tidak melecehkan martabat danharga dirinya;

h. Memiliki rasa tanggung jawab yangdiwujudkan dalam bentuk komitmenterhadap tugas atau kewajibannya;

i. Memiliki kemampuan berinteraksi sosial (human relationship) yang diwujudkan dalam bentuk hubungan persahabatan, persaudaraan, atau silaturrahim dengan sesama manusia;

j. Memiliki kemampuan dalammenyelesaikan konflik (masalah) baikbersifat internal maupun dengan oranglain; dan

k. Memiliki kemampuan untuk mengambil keputusan secara efektif.

2. Fungsi Bimbingan Pribadi-Sosial

Menurut Nurihsan yang dikutip oleh Emmi Khalilah dalam junalnya, menjelaskan Fungsi dalam bimbingan pribadi-sosial yang diungkapkan yaitu: ${ }^{15}$

a. Berubah menuju pertumbuhan. Pada bimbingan pribadisosial, konselor secara be rkesin a m bunga $n$

15 Emmi Khalilah, "Layanan Bimbingan dan Konseling Pribadi Sosial dalam Meningkatkan KeterampilanHubungan Sosial Siswa”, JIGC,(Vol. 01 No. 01. Juni, 2017), 50. 
memfasilitasi individu agar mampu menjadi agen perubahan (agent ofchange) bagi dirinya dan lingkungannya. Konselor juga berusaha membantu individu sedemikian rupa sehingga individu mampu menggunakan segala sumber daya yang dimilikinya untuk berubah.

b. Pemahaman diri secara penuh dan utuh. Individu memahami kelemahan dan kekuatanyang ada dalam dirinya, serta kesempatan dan tantangan yang ada diluar dirinya. Padadasarnya melaluibimbingan pribadisosial diharapkan individu mampu mencapai tingkatkedewasaan dan kepribadian yang utuh dan penuh seperti yang diharapkan, sehinggaindividu tidak memiliki kepribadian yang terpecah lagi dan mampu mengintegrasi diridalam segala aspek kehidupan secara utuh, selaras, serasi dan seimbang.

c. Belajar berkomunikasi yang lebih sehat. Bimbingan pribadi sosial dapat berfungsi sebagaimedia pelatihan bagi individu untuk berkomunikasi secara lebih sehat denganlingkungannya.

d. Berlatih tingkah laku baru yang lebih sehat. Bimbingan pribadisosial digunakan sebagaimedia untuk menciptakan dan berlatih perilaku baru yang lebih sehat.

e. Belajar untuk mengungkapkan diri secara penuh dan utuh. Melalui bimbingan pribadisosial diharapkan individu dapat dengan spontan, kreatif, dan efektif dalammengungkapkan perasaan, keinginan, dan inspirasinya.

f. Individu mampu bertahan. Melalui bimbingan pribadisosial diharapkan individu dapatbertahan dengan keadaan masa kini, dapat menerima keadaan dengan lapang dada, danmengatur kembali kehidupannya dengan kondisi yang baru.

g. Menghilangkan gejalagejala yang disfungsional. Konselor membantu individu dalammenghilangkan atau menyembuhkan gejala yang menggangu sebagai akibat dari krisis.

h. Membantu siswa (konseli) agar mampu mengembangkan kompetensi nya sebagaiberikut:

3. Jenis-jenis Masalah Pribadi Sosial Adapun jenis-jenis masalah pribadi sosial yang dialami siswa adalah sebagai berikut: 
a. Masalah Pribadi, yang terdiri menjelaskan, Bimbingan pribadi dari: (1) Merasa malas sosial diarahkan untuk memantapkan untuk melaksanakan ibadah kepribadian dan mengembangkan : shalat,shaum, dan amal kemampuan siswa dalam menangani saleh lainnya. (2) Kurang memiliki kemampuan masalah-masalah dirinya. Bimbinganini untukbersabar danbersyukur. (3) Masih memiliki kebiasaan berbohong. (4) Masih memiliki kebiasaanmenyontek. Kurang motivasi untuk mempelajari agama. (6) Stress, (7) Depresi, (8) Putusasa, (9) Belum memiliki rasa disiplin. (10) Belum dapat menghormati orang tua secara ikhlas, (11) Dalam melakukan perbuatan tanpa dipertimbangkan resikonya. (12) Masih merasarendah diri (Inferiority)

b. Masalah Sosial, yang terdiri dari: (1) Kurang menyenangi kritikan orang lain. (2) Kurang memahami etika pergaulan. (3) Merasa malu untuk berteman dengan lawan jenis. (4) Kurang mampu menyesuaikan diri. (5) Penyakit sosial seperti; tawuran, gang motor, pemalakan,pencurian, dan sebagainya. ${ }^{16}$

4. Arah Bimbingan Pribadi Sosial

Menurut Nurihsan yang dikutip oleh Emmi Khalilah dalam junalnya,

16 Ibid., 51. merupakan layanan yang mengarah pada pencapaian pribadiyang seimbang dengan memperhatikan keunikan karakteristik pribadi serta ragam permasalahan yang dialami olehsiswa. Bimbingan pribadi sosial diberikan dengan cara menciptakan lingkungan yangkondusif, interaksi pendidikan yang akrab, mengembangkan sistem pemahaman diri, dan sikapsikap yang positif, serta keterampilanketerampilan pribadi-sosial yang tepat.

Menurut Sukardi, yang dikutip oleh Emmi Khalilah dalam junalnya, menjelaskanbidangbimbinganinidapat dirinci menjadi pokok-pokok berikut: (a) Pemantapan sikap dan kebiasaan serta pengembangan wawasan dalam beriman dan bertakwa kepada TuhanYang Maha Esa. (b) Pemantapan pemahaman tentang kekuatan diri dan pengembangannya untuk kegiatan yang lebih kreatif, produktif, dan normatif baik dalam keseharian maupun untukperan di masa yang akan datang. (c) Pemantapan pemahaman tentang bakat dan minat pribadidan penyaluran dan pengembangan nya pada/melalui kegiatan yang kreatif 
dan normatif danproduktif. (d) Pemantapan tentang kelemahan diri dan usaha penanggulangan nya. (e) Pemantapankemampuan pengambilan keputusan. (f) Pemantapan kemampuan mengarahkan diri sesuai dengan keputusan yang telah diambil. (g) Pemantapan dalam perencanaan dan penyelenggaraan hidup sehat jasmani dan rohani. (h) Pemantapan kemampuan berkomunikasi.(i)

Pemantapan kemampuan menerima dan menyampaikan argumentasi secara dinamis, kreatif,normatif dan produktif. (j) Pemantapan kemampuan bertingkah laku dan berhubungan sosialdengan penuh tanggung jawab(k) Pemantapan hubungan yang dinamis dan harmonis denganteman sebaya, orang tua, dan masyarakat sekitar. (l) Orientasi tentang kehidupan berkeluarga. ${ }^{17}$

\section{Strategi dan Teknik Bimbingan dan Konseling Prbadi-Sosial}

Struktur program bimbingan perkembangan yan komprehensif terdiri atas empat komponen. Yakni Pelayanan dasar, Pelayanan responsif, Perencanaan individual, dan dukungan sistem.penjelasannya yakni sebagai berikut.

\section{Pelayanan Dasar}

Pelayanan dasar bimbingan yaitu layanan umum yang diperuntukkan bagi semua murid.layanan terarah bagi pengembangan perilaku atau kompetensi yang harus dikuasai murid dengan tugas perkembangannya. layanan dasar ini disebut juga sebagai kurikulumbimbingan yang merupakan inti dari program bimbingan perkembangan. ${ }^{18}$

\section{a. Bimbingan kelas}

Layanan dasar diperuntukkan bagi semua siswa. Hal ini berarti bahwa dalam peluncuran program yang telah dirancang menuntut konselor untuk melakukan kontak langsungdengan para siswa di kelas. Secara terjadwal, konselor memberikan layanan bimbingan kepada para siswa. Kegiatan bimbingan kelas ini dapat berupa diskusi kelas atau brainstorming.

b. Pelayanan orientasi

Pelayanan orientasi adalah sebuah layanan bimbingan yang dilaksankan oleh konselor kepada siswa untuk memperkenalkan lingkungan yang baru dimasukinya atau yang baru diketahuinya terutama hal-hal yang terdapat disekitar lingkungan sekolah maupunmadrasah agar memperlancar iklim pendidikan.40 Layanan

18 Mochamad Nursalim, Bimbingan dan Konseling Pribadi-Sosial, (Yogyakarta: Ladang Kata), 43. 
orientasi terutama ditujukanpada siswa baru agar mereka lebih mudah dalam penyesuaian diri, baik dengan lingkungansekolah maupun dengan kebijakan-kebijakan yang ada di sekolah.

\section{c. Pelayanan informasi}

Layanan ini diberikan pada siswa berupa pemberian pemahaman tentang berbagai hal yang diperlukan untuk menjalani tugas dan kegiatan di sekolah dan untuk menentukan danmengarahkan tujuan hidup. Berbagai informasi sangat penting diberikan kepada siswadengan alasan: (1) agar siswa memiliki pengetahuan tentang lingkungan yang diperlukan untuk memecahkan masalah yang berkaitan dengan lingkungan sekitar, pendidikan, jabatan, maupun sosial budaya, (2) memungkinkan siswa untuk menentukan arah hidupnya, menentukan hak yang harus dilakukan serta cara bertindak yang kreatif dan dinamis berdasarkan informasi yang diperoleh, (3) setiap individu memiliki keunikan yang akan membawanya pada kekhasan dalam penentuan keputusan dan bertindak sesuai aspek kepribadian masingmasing. Layanan informasi, berarti memberikan informasi seluasluasnya kepada peserta didik terkait dengan kegiatan akademis dan non akademis untukmasa sekarang dan masa yang akan datang, meliputi bidang pribadi, sosial, belajar, dankarir.

d. Bimbingan kelompok

Bimbingan kelompok yang dimaksud adalah sebuah bentuk pelayanan untuk menyediakan pelayanan-pelayanan yang berfokus pada penyediaan informasi dan pengalaman melaluisebuah aktivitas kelompok yang terencana dan teroganisir. Bimbingan ini biasa dilakukanpada kelompok kecil (5-10 orang) yang ditujukan untuk merespon kebutuhan dan minatpara siswa, topik yang didiskusikan dalam bimbingan kelompok ini, adalah masalah yang bersifat umum (common problem) dan tidak rahasia, seperti: cara-cara belajar yang efektif, kiat-kiat menghadapi ujian,dan mengelola stress. Layanan bimbingan kelompok ditujukanuntuk mengembangkan keterampilan atau perilaku baru yang lebih efektif dan produktif.

e. Pelayanan pengumpulan data

Pelayanan ini merupakan usaha untuk memperoleh data dan atau informasi tentang siswa dengan berbagai teknik, metode, dan alat baik yang berupa tes maupun non-tes yang berupaya untuk assessment. Layanan ini bertujuan untuk memberikan gambaran yang jelas tentang informasi individual siswa dengan 
menghubungkan satu aspek dengan yanglainnya. ${ }^{19}$

\section{Pelayanan Responsif}

Layanan responsif yaitu layanan yang diarahkan untuk membantu murid mengatasi masalah-masalah yang dihadapi pada saat itu. Oleh karena itu, layanan responsif akan mengandung layanan-layanan yang bersifat penanganan krisis, remediatif dan preventif. ${ }^{20}$

a. Konseling individual dan kelompok

Sebagaimana telah diketahui bersama, konseling merupakan hubungan yang berupaya memberi bantuan yang berfokus pada penyelesaian dan pengentasan problematika siswa yang berkaitan dengan hambatan yang dialaminya baik bersifat perkembangan maupun pertumbuhan. Melalui konseling, peserta didik (konseli) dibantu untuk mengidentifikasi masalah, penyebab masalah, penemuan alternatif pemecahan masalah, dan pengambilan keputusan secara lebih tepat. Konseling ini dapat dilakukan secara individual maupunkelompok.

b. Referal (rujukan atau alih tangan 53.

19 Emmi Khalilah, "Layanan Bimbingan...,

20 Mochamad Nursalim, Bimbingan dan Konseling...,46. kasus)

Pelayanan yang baik adalah usaha yang dilaksanakan dan diselenggarakan bagi merekayang benar-benar ahli. Begitu pula dalam bentuk pelayanan bimbingan dan konseling tidakhal dapat diatasi oleh diri konselor pribadi, Apabila konselor merasa kurang memiliki kemampuan untuk menangani masalah konseli, maka sebaiknya dia mereferal atau mengalih tangankan konseli kepada pihak lain yang lebih berwenang, seperti psikolog,psikiater, dokter, dan kepolisian. Pada umumnya, alih tangan (referal) dilakukan untuk kasuskasus tertentu seperti, depresi, tindak kejahatan (kriminalitas), kecanduan narkoba, danpenyakit kronis.

c. Kolaborasi dengan wali kelas

Konselor berkolaborasi dengan guru dan wali kelas dalam rangka memperoleh informasi tentang peserta didik (baik masalah pribadi, sosial, belajar dan karir), membantu memecahkan masalah peserta didik, dan mengidentifikasi aspek-aspek bimbingan yang dapat dilakukan oleh guru mata pelajaran.

d. Kolaborasi dengan orang tua

Upaya kerjasama antara Konselor dengan para orang tua peserta didik untukmengembangkan perkembangan siswa. Kerjasama ini penting agar proses bimbingan terhadap peserta 
didik tidak hanya berlangsung di Sekolah/Madrasah, tetapi juga oleh orangtua di rumah.

e. Kolaborasi dengan pihak yang terkait

Kolaborasi dengan pihak-pihak terkait di luar sekolah/madrasah ; yaitu berkaitan dengan upaya sekolah/ madrasah untuk menjalin kerjasama dengan unsur-unsur masyarakatyang dipandang relevan dengan peningkatan mutu pelayanan bimbingan. Jalinan kerjasama ini seperti dengan pihakpihak (1) Instansi pemerintah, (2) Instansi swasta, (3) organisasiprofesi, seperti ABKIN (Asosiasi Bimbingan dan Konseling Indonesia), (4) Para ahli dalambidang tertentu yang terkait, seperti psikolog, psikiater, dan dokter, (5) MGP (MusyawarahGuru Pembimbing).

\section{f. Konsultasi}

Merupakan sebuah upaya untuk memperoleh informasi baik yang dilakukan oleh konselor atau pihak terkait tentang kondisi konseli atau siswa. Menurut Gibson, konsultasi dapat dibagi menjadi dua, Pertama, Konsultasi Triadik atau konsulasi pihak ketiga seperti guru guru yang menghadapi siswa-siswa yang bermasalah. Kedua, Konsultasi Proses, adalah sebuahupaya untuk menjalankan bimbingan. g. Bimbingan Teman Sebaya (Peer Guidance/Peer Facilitation)

Bimbingan teman sebaya ini adalah bimbingan yang dilakukan oleh peserta didik terhadap peserta didik yang lainnya. Peserta didik yang menjadi pembimbing sebelumnya diberikan latihan atau pembinaan oleh konselor. Peserta didik yang menjadi pembimbing berfungsi sebagai mentor atau tutor yang membantu peserta didik lain dalam memecahkanmasalah yang dihadapinya, baik akademik maupun non-akademik.

h. Konferensi Kasus

Adapun yang dimaksud dari konferensikasusadalah sebuah kegiatan untuk membahas permasalahan peserta didik dalam suatu pertemuan yang dihadiri oleh pihak-pihakyang dapat memberikan keterangan, kemudahan dan komitmen bagi terentaskannya permasalahan peserta didik itu. Pertemuan konferensi kasus ini bersifat terbatas dan tertutupkarena hanya dihadiri oleh pihak-pihak terkait saja yang berkomitmen untuk memecahkan permasalahan.

i. Kunjungan Rumah

Dalam menangani siswa sering sekali akurasi informasi dan pengetahuan tentang suasana dan kondisi kehidupan siswa di rumah atau keluarga.Untuk itu, agar konselormempunyai pemahaman 
yang komperhensip maka kunjungan rumah baiknya dilakukan. Akan tetapi kunjungan rumah tidak perlu dilakukan konselor kepada seluruh siswa yangditanganinya melainkan cukup bagi siswa yang memiliki kadar permasalahan yang besar dalamrumah tangga. ${ }^{21}$

Adapun perencanaan individual yaitu layanan yang maksudkan untuk mmebantu murid mengembangkan dan mengimplementasikan rencana pribadi sosial. Tujuan utama dari komponen ini adalah untuk membantu murid memantau dan memahami pertumbuhan dan perkembangannya secara proaktif.

Tujuan layanan perencanaan individual adalah membibing murid untuk meencanakan, memonitor, dan mengelola rencana pengembangan pribadi-sosial oleh dirinya sendiri. Konselor dapat menggunakan berbagai nara sumber, staf, informasi, dan kegiatan serta memfokuskan nara sumber untuk seluruh murid dan membantu murid secara individual untuk mengembangkan dan mengomplementasikan perencanaaan pribadi.

Konseli menggunakan informasi tentang pribadi, sosial, pendidikan, dan karir yang diperolehnya 55

21 Emmi Khalilah, "Layanan Bimbingan..., untuk (1) merumuskan tujuan, dan merencanakan kegiatan (alterntif kegiatan) yang menunjang pengembangan dirinya, atau kegiatan yang berfungsi untuk memperbaiki kelemahan dirinya; (2) melakukan kegiatan atau perencanaan yang telah ditetapkan, dan (3) mengevaluasi kegiatan yang telah dilakukannya. ${ }^{22}$

Dukungan sistem yaitu komponen yang berkaitan dengan aspek manajerial yang mencakup antara lain pengenmbangan program, pengembangan staf, alokasi dana dan fasilitas, kerjasama dengan orang tua dan sumber lainnya, riset dan pengembangan. ${ }^{23}$

Layanan ini memberikan dukungan pada konselor dalam mempelancar penyelenggaraan program pendidikan di sekolah. Dukungan sistem ini meliputi aspekaspek:(1) pengembangan network, (2) kegiatan manajemen, (3) riset dan pengembangan.

\section{E. Teknik Bimbingan dan Konseling Prbadi-Sosial}

ABKIN dalam rambu-rambu penyelenggaraan Bimbingan dan Konseling dala Jalur Pendidikan Formal, mengemukakan beberapa

22 Mochamad Nursalim, Bimbingan dan Konseling...,5 1-53.

23 Ibid., 55. 
macam teknik bimibingan yang dapat digunakan utnuk membantu perkembangan murid, yaitu: ${ }^{24}$

1. Konseling Individu

Konseling individu adalah merupakan bantuan yang sifatnya terapeutik yang diarahkan untuk mengubah sikap dan perilaku murid. Konseling dilaksanakan melalui wawancara wawancara langsung dengan murid yang normal, bukan yang mengalami kesulitan kejiwaan melainkan hanya mengalami kesulitan dalam penyesuaian diri dalam pendidikan, pekerjaaan dan kehidupan sosial.

\section{Konsultasi}

Konsultasi merupakan salah satu teknik bimbingan yang penting sebab banyak masalah karena sesuatu hal akan lebih berhasil jika ditangani secra tidak langsung oleh konselor. Konsultasi dalam pengertian umum dipandang sebagai nasihat dari seorang profesional. Pengertian konsultasi dalam program bimbingan dipandang sebagai suatu proses menyediakan bantuan teknis untuk guru, orang tua, administrator, dankonselor lainnya dalam mengidentifikasi dan memperbaiki masalah yang membatasi efektifitas murid atau sekolah.

24 Ibid.,58-59.
3. Nasihat

Nasihat merupakan salah satu teknik bimbingan yang dapat diberikan oleg guru. Pemberian nasihat hendaknya memperhatikan halhal sebagai berikut: (a) Berdasarkan masalah atau kesulitan yang dihadapi oleh murid. (b) Diawali dengan menghimpun data yang berkaitan dengan masalah yang dihadapi. (c) Nasihat yang diberikan bersifat alternatif yang dapat dipilh oleh murid, disertai kemungkinan keberhasilan dan kegagalan. (d) Penentuan keputusan diserahkan kepada murid, alternatif mana yang kan diambil, serta (e) hendaknya murid mau dan mampu mempertangungjawabkan keputusan yang diambilnya.

4. Bimbingan Kelompok

Bimbingan kelompok 'merupakan bantuan terahadap murid yang dilaksanakan dalam situasi kelompok. Bimbingan kelompok dimaksudkan untuk mencegah berkembangnya maslaah atau kesulitan pada diri murid. Isikegiatanbimbingankelompokterdiri atas penyampaian informasi ataupun aktivitas kelompok yang berkenaan dengan masalah pendidikan, pekerjaan pribadi dan sosial yang tidak disajikan dalam bentuk pelajaran.

Pada umumnya, aktivitas kelompok menggunakan prinsip dan proses dinamika kelompok, seperti dalam 
kegiatan diskusi, sosiodrama, bermain peran, simulasi dan lain-lain. Bimbingan melalui aktivitas kelompok lebih efektif karena selain peran individu lebih aktif, juga memungkinkan terjadinya pertukaran pemikiran, pengalaman, rencana dan penyelesaian masalah.

5. Konseling Kelompok

Konseling kelompok merupakan upaya bantuan kepada murid dalam rangka memberikan kemudahan dalam perkembangan dan pertumbuhannya. Selain bersifat pencegahan, konseling kelompok dapat pula bersifat penyembuhan. Konseling kelompok bersifat pemberian kemudahan dalam pertumbuhan dan perkembangan murid, dalam arti bahwa konseling kelompokmenyajikandanmemberikan dorongan kepada murid-murid yang bersangkutan untuk mengubah dirinya selaras dengan minatnya sendiri.

Klien-klien dalam konseling kelompok pada dasarnya adalah murid-murid normal yang memiliki berbagai kepedulian dan persoalan yang tidak memerlukan perubahan kepribadian dalam penanganannya. Klien dalam konseling kelompok dapat menggunakan interaksi dalam kelompok untuk meningkatkan pemhaman dan penerimaan terhadap nilai-nilai dan tujuantujuan tertentu, untuk mempelajari atau menghilangkan sikap-sikap dan perilaku tertentu.

Berikut ini pada gambar di bawah ini akan digambarkan secara visual implementasiproseslayananbimbingan dan konseling pribadi sosial dalam menumbuhkan sikap positif terhadap tata tertib.

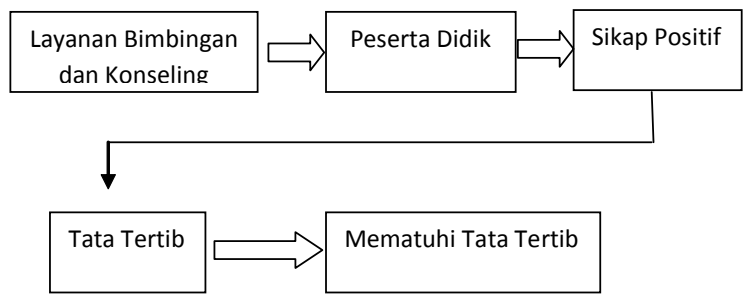

Impelentasi layanan dalam bimbingan dan konseling pribadi sosial di terapkan untuk peserta didik agar mengerti apa itu sikap positif, cara mengubahnya dan betapa pentingnya sikap positif. Serta menjelaskan tentang tata tertib, tujuan diciptaknnya tata tertib serta manfaat yang bisa diperoleh ketika peserta didik mematuhi tata tertib. Dengan bimbingan yang dilakukan secara terus menerus menggunakan teknik-teknik dan kolaborasi antar teori konseling diharapkan mampu menjadikan peserta didik memiliki sikap posittif sehingga mereka mematuhi tata tertib yang ada.

\section{f. Penutup}

Layanan bimbingan dan konseling pribadi-sosial adalah layanan konseling yang diberikan khusus untuk 
menangani masalah pribadi dan sosial yang dialami seorang klien. Layanan konseling diberikan yang di tujukan agar klien mampu mengubah sikap dan perilaku yang tidak baik menjadi lebih baik dan dengan keinginannya sendiri. Impelentasi layanan dalam bimbingan dan konseling pribadi sosial di terapkan untuk peserta didik agar mengerti apa itu sikap positif, cara mengubahnya dan betapa pentingnya sikap positif. Serta

\section{Daftar Pustaka}

Eka Novia Anggraini, Tjipto Subadi, "Pengelolaan Tata Tertib Sekolah Menengah Pertama", Varia Pendidikan,(Vol. 27, No. 2, Desember 2015)

Umar

Sulaiman, "Analisis

Pengetahuan, Sikap, Dan Perilaku Beragama Siswa Kasus pada Siswa SLTP Negeri I dan MTs Negeri Bulukumba", Jurnal Auladuna,(Vol. 1 No. 2 Desember 2014)

Eka Ajeng Rahmi Pinahayu, "Menumbuhkan Sikap Positif Dan Kreativitas Peserta Didik Melalui Media Pembelajaran Mahjong Trigonometri”, Jurnal Ilmiah Pendidikan Matematika, (Volume 2 Nomor 1P-ISSN: 25027638; E-ISSN: 2502-8391) menjelaskan tentang tata tertib, tujuan diciptaknnya tata tertib serta manfaat yang bisa diperoleh ketika peserta didik mematuhi tata tertib. Dengan bimbingan yang dilakukan secara terus menerus menggunakan teknik-teknik dan kolaborasi antar teori konseling diharapkan mampu menjadikan peserta didik memiliki sikap posittif sehingga mereka mematuhi tata tertib yang ada.

Darmiyati Zuchdi, "Pembentukan Sikap", Cakrawala pendidikan, (Nomor 3, Tahun XlV, November 1995)

Aprilia Nur Kurniawati,dkk, "Pengaruh Motivasi Terhadap Kedisiplinan Siswa Dalam Mematuhi Tata Tertib Sekolah Di Sekolah Menengah Atas (Sma) Al Islam 1 Surakarta”, Educitizen,(Vol. 2 No.

2. November, 2017)

Dwi Endro Lestari, "Upaya Menangani Siswa Yang Sering Melanggar Tata Tertib Sekolah Melalui Layanan Konseling Kelompok", Jurnal Ilmiah Pendidikan Bimbingan Dan Konseling

Nadya Yulianty S, "Efektivitas Bimbingan Pribadi-Sosial Untuk Mengembangkan Kompetensi 
Intrapersonal Peserta Didik", Jurnal Bimbingan dan Konseling Islam, (Vol. 05. No. 01. 2015)

Emmi Kholilah Harahap, "Layanan Bimbingan Dan Konseling Pribadi Sosial Dalam Meningkatkan Keterampilan Hubungan Sosial Siswa”, TAJDID, (Vol. XIV, No. 2, Juli-Desember 2015)

Yahya AD dan Winarsih, "Layanan Bimbingan Pribadi-Sosial Dalam Meningkatkan Komunikasi Interpersonal Peserta Didik Kelas Xi Sma Negeri 2 Padang Cermin
Kabupaten Pesawaran”, Jurnal Bimbingan dan Konseling,(ISSN 2089-9955 03, 1, 2016)

Emmi Khalilah, "Layanan Bimbingan dan Konseling Pribadi Sosial dalam Meningkatkan Keterampilan Hubungan Sosial Siswa”, JIGC, (Vol. 01 No. 01. Juni, 2017)

Mochamad Nursalim, Bimbingan dan Konseling Pribadi-Sosial, (Yogyakarta: Ladang Kata) 